\title{
Influence of Education on Practice of Contemporary Wood Carving in Awka Town, Anambra State
}

\author{
Nwanna Clifford Ezekwe ${ }^{1, *}$, Nwanna Uju Christiana² \\ ${ }^{1}$ Department of Fine and Applied Arts, Faculty of Environmental Sciences, Nnamdi Azikiwe University, Awka, Nigeria \\ ${ }^{2}$ Department of Guidance and Counselling, Faculty of Education, Nnamdi Azikiwe University, Awka, Nigeria
}

Received November 24, 2019; Revised December 25, 2019; Accepted December 30, 2019

Copyright $\odot 2020$ by authors, all rights reserved. Authors agree that this article remains permanently open access under the terms of the Creative Commons Attribution License 4.0 International License

\begin{abstract}
Informal and formal education systems have played very important role in the Educational development of Africa. Even formal educational system which characterized the present system of education, did not only develop from non - formal education but has consistently shown influence of non - formal education. It is regrettable that most scholars show little interest on the relevance of non-formal education in formal educational system, hence there is a dearth of scholarly Literature on the subject. In view of this problem this study examined the influence of the education systemon the Awka wood carving industry. The study employed a survey design, while a descriptive method was used in data analysis. Sources of data include both primary and secondary sources. The primary sources are mainly Oral, while secondary sources are written materials, both published and unpublished. The result of the study showed that Western education has influence on wood carving training in Awka. It therefore recommends that traditional wood carving methods should be introduced to the curriculum for teaching academic art in Nigeria to acquaint students with knowledge of their indigenous arts and culture and to draw inspirations from them for modern art productions.
\end{abstract}

Keywords Influence, Education, Practice Contemporary Woodcarving

\section{Introduction}

Education which serves as an instrument for the development of both the individual child and the society is not new to any race, rather every society, globally, has evolved one form of educational system or the other. Before the introduction of western education around $19^{\text {th }}$ century and Islamic education which started earlier, in
Nigeria, there had been a traditional system of education. Infact, western (formal) education systemin Nigeria started in 1842 by Christian missionaries. Their activity was concentrated within Lagos area (Badagry and Abeokuta) and later to other parts of southern Nigeria.

The aim of these early mission schools emphasized the training of indigenous manpower to carry out evangelical work to the various communities and training of messengers, clerks and cleaners of various missions and British businessmen. This training excluded arts and sciences. Again, during this period, the colonial government was silent over educational activities of the missions [Amaele, I]. However, by mid $-20^{\text {th }}$ century a noticeable change gradually creeped into the Nigerian education system. One of the major causes of this change was the Asquith Commission, which was set up in 1943, to look into the problem of Nigerian education system. One of their major recommendations was that "facilities should be provided for the training of arts and science teachers to control the problem of lack of teachers in the grammar schools".

Although, their recommendations were upheld and its implementation led to establishing the training in arts and science in the Nigeria premier higher institutions of learning: Yaba College of Technology, and later Zaria College of Arts and Science and the University College, Ibadan. Their art training mirrored the European art pedagogy and curriculum with little or no influence of Nigeria's systemof art training and practice. This situation persisted until the 1960s when Nigeria gained independence from Britain. The spirit of independence affected most areas of life in Nigeria, including arts. Most Nigerian visual artist and architects, though trained in the western education system, started looking back to their rich indigenous heritage for inspiration and identity. This development saw conscious adaptations of indigenous art styles and influences which still persist in the Nigerian art scene, especially wood carving and other aspects of 
contemporary arts. It is however, regrettable that these influences of non formal/indigenous art on contemporary art training and practice have not received enough scholarly attention.

Wood carving under the indigenous education system was non-formal, here training and acquisition of knowledge is seen as a hereditary tradition. Knowledge is transmitted informally from father to son. Often times, at a very early stage a child is found practicing with tools and grows to become a full fledge carver. This system of traditional education could still be seen in Awka town among the few existing wood carvers and blacksmiths. Awka town is a known arts/craft centre since the precolonial times and their influence on contemporary wood carvers in Awka is not in doubt.

Writing on the relationship between in formal education system and formal education system in Nigeria, Freeborn Odiboh observed that;

Another type of workshop is the informally-formalized master - apprentice type which though exist outside formal education structure, but has an in-built formalized structure. These are very common in Nigeria, particularly among the artisans who undergo an elaborately structured apprenticeship training with agreements between the master and the apprentice, specified period of training, sanctions for omission, certificate awarding and others [2]

Formal trained wood carvers/sculptures, who are mainly graduates of art schools from the various tertiary institutions in Nigeria, often join services of traditional carvers after graduation to sharpen their skills. Some art students even involve non-formal training in tertiary institutions. Here they deliberately go for industrial attachment for one semester or session in traditional wood carving centers to gain insight into indigenous traditional carving techniques and practices.

\section{Statement of the Problem}

There is a dearth of scholarly literature on traditional wood carving, non-formal and informal education systems in Awka town. The lack of interest in this important system of learning and practice is regrettable and has negatively affected the educational history of Nigeria, whose enormous influence on contemporary wood carving is not in doubt. Few studies carried out by scholars did not address the traditional wood carving in Awka. This has then constituted a problem that needs to be tackled, hence the present study.

\subsection{Purpose of the Study}

The main purpose of the study is to examine the influence of formal education on the contemporary training and practice of traditional wood carving in Awka, Anambra state. Specifically, the study sought to:

- The establish that Awka town has been a renowned centre for wood carving

- Ascertain the present status of Awka traditional wood carving industry

- Assess the influence of education on training of contemporary wood carvers in Awka town.

- Determine the influence of informal training on the products of contemporary Awka wood carving industry

- $\quad$ Find out the economic prospects of Awka wood carving industry as it relates to the socio-economic life of the people

\subsection{Scope of the Study}

For this study to be effective, it is delineated to the influence of traditional wood carving industry on the training and practice of contemporary wood carving in Awka town. The study also made an in depth survey of traditional wood carving in Awka, its training and techniques of production.

\subsection{Significance of the Study}

This work will be beneficial to Fine Art practitioners especially, sculptors, Art historians and educationists. It is an eye opener on the level of technical proficiency and discipline of informal art training in Awka.

The relevance will also be felt by Anambra state Arts, tourism and Diaspora Affairs Ministry. It will guide them in taking decisions and formulation of policies on matters that concern visual arts in the state. Finally, this study will be a reference point to researchers that will embark on the subject or related subject in future.

\subsection{Research Questions}

1. Is Awka town renowned for wood carving craft?

2. What is the present status of Awka traditional carving industry today?

3. To what extent does informal art education influence training of contemporary wood carving in Awka

4. To what extent has the traditional informal carving training influenced the services and products of contemporary wood carving in Awka?

5. What are the economic prospects of wood carving in Awka in relation to the socio-economic life of the people?

\subsection{Research Hypotheses}

To a large extent there is no negative variance between the style and technique and product of Non-formal trained carvers in Awka, and that of formal trained carvers in Awka.

There is no influence of Non formal wood carving in 
Awka on the formal wood carving system.

There is no negative variance between the demand of the products of Non formal trained artists and the demand of the products of formal trained wood carvers.

\subsection{Literature Review}

Related literature was reviewed under the following subheadings: conceptual framework, theoretical framework, empirical review and summary of literature reviewed.

\subsection{Conceptual Framework}

Education is the process or art of imparting knowledge, skill and judgment. It could also be seen as facts, skills and items that have been learned either formally or informally. The word education is exclusively used for the development of human beings in the cognitive, affective, psychomotor and psycho productive domains. There is a general agreement among educationist and educators that education involves a desirable change in human behavior through the process of teaching and learning. This means that a human being who exhibits undesirable change in human behavior from the point of view of the acceptable societal norms cannot be seen as an educated person, despite the fact that the person had had passed through an educational institution. Amaele upheld this view when he states thus;

The society, generally, expects a kind of change from an educated person. Education, as a process of initiating the child into cherished norms and skills, is designed and implemented by the more matured or adult members of the society to effect the desirable changes in the younger ones from one generation to the other [3]

Etymologically, education derived its meaning from two Latin words educare and educere respectively. The word educare translates thus "to train or to inform or to mould". Education here seems to reflect the sociological perspective. In other words, educare implies that the society trains, forms or moulds the individual to achieve the society needs and aspirations. This perspective is not based on the natural potentials of the individual child.

On the other hand, the word "educare could be interpreted to mean; "to build, to lead or to develop". This perspective of the concept is mostly favoured by the humanist who insists that the function of education is to develop the natural potentials in the child to enable him function in the society according to his/her abilities, interest and needs. This perspective of the concept of education is child centered, whereas the former is a society or subject matter- centred.

From the on-going discussion, therefore, education could be understood to mean the total development of the individual child through acceptable methods and techniques, according to his abilities and interest, as well as the needs of the society, to take his rightful place and contribute adequately to the advancement of his society.

A lot of scholars have categorized education into different types:Formal, informal and non-formal.

Kasfi shared the opinion that artists whether formally trained, informally trained or self-taught occupy different class positions in the society.

He states;

They live and react to the same world and many of the same collective experiences. These include; the linkages of history and social differentiation from weft to warpt of a single fabric [4].

Awogbade in "Out of School Education: Exploration in the Visual Arts" categorised out of school education programme to include;

1. Traditional schoolsystem

2. Industrial training schools

3. Improvised schoolsystem

While pointing out the influence of the out of school education on formal education, she avers;

...Informal (out of station) visual experiences complement the formal (in-school) experience. It has also been established that most visual artists that have passed through in-school art training enroll in an out of school' visual art education centre to acquire hands-on practical skills needed to become an all-round professional artist who do not only practically express themselves but can also defend their visual arts literarily [5].

In support of this Arogbade's assertion, Sulyman, stated: It is therefore necessary to note that the desire of people to acquire skills through apprenticeship, both in the past and present, is geared towards fulfilling certain set objectives: the transmission of a people's culture from one generation to another and a means of earning a living [6].

\subsection{Forms of Education}

Education can generally categorized into three forms namely: formal, informal and non-formal. By these various forms some people might be receiving education without knowing it. However, there are limits to what each from of education can affect the receiver, the type of society one finds is most appropriate for one. It is also important to observe that so many people have passed through all the three forms of education without knowing.

\subsection{Formal Education}

This is the type of education which is received in the regular formal school setting for instance, the primary, secondary and tertiary institutions. Formal education has well determined setting where well trained and equipped 
teachers interact, on regular basis with the learners on planned education processes. The curriculum, the learning environment, instructional materials, testing, evaluation, human resources are planned ahead of time to achieve specific objectives within the time frame. Everything is patterned from the entry point to the exit point. The books, the classroom, the pupils, teachers and curriculum are selected and formalized.

\subsection{Informal Education}

Informal education includes all other agencies of learning outside the formal learning system. These agencies include the family, church/mosque, peer-group and mass media. Informal education can also be received in the market, farm, along the road among others. Though not deliberately planned like the formal education, informal education provides learning opportunities for the child to develop his natural potentials within a given limit. It enlarges the child's scope of learning and helps to build up the comprehensive experience of the formal education system.

What the child learns from his/her mother, father, elderly ones, peer groups, associations etc, fall under the informal education. In this form of education, the child or the adult can learn from one another or from the society, consciously or land unconsciously [7].

Informal education is still relevant today. It can also provide some raw data to the child, which could be refined in the formal school system. But he should be guided so that what he/she learns through this form of education would not be negative form of education

\subsection{Non-formal Education}

This form of education has some basic characteristics of formal education like planned programme of action, contact persons, programmed assignment or examination and others, but it is not within the regular school system. Non-formal education is mainly received through the traditional apprenticeship system, workshops, seminars, corres pondence and mass media. In the case workshops and seminars, non-formal education is used to equip the individual with some basic skills, attitudes and intelligence required for human and societal growth at one particular time or the other. In the case it is occasional or adhoc. But in corres pondence cases, the learning process is spread over the years and it lacks the regular person to person interaction. It could be seen as a complimentary form of education. However, some informal education such as wood carving provides for occupational and professional training. In traditional Awka society, knowledge of carving is either from the wood carver's parents through hereditary caste of master carver passing the knowledge to his descendants or through apprenticeship training.

The apprenticeship systemis the method of acquiring the knowledge of wood carving through the master/servant relationship. This system is mainly for children whose parents are not carvers. Admission requirement is based mainly on good moral background of the apprentice. At times fees are charged by the master carver before he could accept to train the apprentice. George Basden attested to this fact when he postulates thus:

Carving among the Igbo is a skilled occupation confined to professional men. The apprentice usually helps the master in his work and in the course of his exercising learns the art of wood carving himself [8].

Under the apprenticeship system the duration of the training is not usually specified based on the age the apprentice but it ranges from four to six years or to when the apprentice becomes proficient in the art or to the age when the servant/the apprentice is old enough to stand on his feet.

From this conceptual clarification it is clear that nonformal and informal education share some characteristics but they are not exactly the same for the purpose of this study both informal and non-formal education system are used interchangeably.

\subsection{Theoretical Framework}

Theories of Art: A theory is a contemplative and logical type of generalizing thinking. It is also a formal statement of the rules on which a subject of study is based. The word 'Theory' originated from the Greek word 'theories' which means, viewing, looking at or beholding. In this sense; Theories mean beholding/Looking at the things that make up the field of art. Ikechukwu Ogugua remarks that:

Scholars have seen art variously. Art is seen as imitation, expression, communication, Quality of experience, empathy pleasure, play, etc. it could be a creation of what is new especially ideas, a creation of visual science rich in aesthetic Value that is not utilitarian at All, but not made for profit or Gain primarily. Art is an imaginative and creative ability.[9].

The first theory of art was propounded by the Greek philosopher, Plato, when he remarked that "art was essentially a matter of imitation of nature". This theory holds that art is an imitation of reality. The crucial questions that could be asked concerning this theory are, what is imitation? and what is the reality that is being imitated? Plato was of the view that a work of art is at least three steps removed from truth; for him reality is located in the world of form/ideas, and nature is a reflection of it, hence just a copy - art too is a copy from copy.

The second theory of art is the 'Representational Theory'. Representation replaced imitation after Aristotle's critique of Plato's theory of art as imitation. While pointing out the flaws in the imitation theory, Grombrich clarifies that;

Although imitation may pre-suppose resemblance, both are not the same imitation is something people try to 
accomplish, something one strives for, succeeds or fails at; whereas resemblance is simply a coincidence. Moreover, while imitation is one-dimensional and unidirectional, resemblance is bi directional; for it has a symmetrical relation with reality while imitation has asymmetrical relation. [10]

In Grombrich's view, is that artists should translate not transcribe, and transpose not copy.

Next is the Theory of "Art as an Expression of Emotion". This theory was spear headed by Veron. According to Veron "art is expression of emotion, a work of art is then a symbol of emotion". Here Veron tries to draw a line between decorative and expressive art, positioning expressive art as proper and as an expression of emotion. $\mathrm{He}$ is of the opinion that it is from this categorization that one can see the difference between an artist and a craftsman; for style, no doubt, belongs to the artist. [12]

Leo Tolstoy came up with the theory of "Art as Communication of Emotions" Tolstoy's theory appears to be an off shoot and an improvement of Eugene Veron's theory. Communication appears to be a step further that expression. There is no separation between art and the recipient in a real work of art. A work of art communicates when the recipient feels the same emotion the artist feels or felt [13].

Summarily, Tolstoy's view of art emphasized the transmission of human emotion as essence of art. Here, there is justification for the interpretation and ideas which artists like Mark Ernest, Paul Klee, Marcel Duchamp among many others of the Dadaist group show in their works. There are other theories by Schilder, Karl Groos and many others whose views are equally acceptable and have added to man's aesthetic discoveries, it is also pertinent to add that these theories are not flawless. They have been criticized by scholars and the flaws in them pointed out. Today we have a multiplicity of definitions of art coming from art scholars, critics and philosophers. Some of the recent definitions of art include that of Anyaeji who defines art as; "An expressive tool which artists constantly conduct exploration of forms, identity, meaning and values in the re-invention of the physical and cultural environment" [14]

\subsection{Learning Theory}

Learning theories are conceptual framework that described how students absorb, process and retain knowledge during learning. Cognitive, emotional and environmental influences as well as prior experience all play a part is how understanding or a word view is acquired or changed and knowledge and skill retained.

The learning theory that is not appropriate for this study is the Methodological Behaviourism. This began as a reaction against the introspective psychology that dominated the late $19^{\text {th }}$ and early $20^{\text {th }}$ centuries. Exponents of this theory such as: B.F. Skinner and J.B. Watson rejected introspections methods as being subjective and unqualifiable. Instead, they focused on objectively observable, qualifiable events and behavior. They argue that since it is not possible to observe objectively or to quantify what occurs in the minds, scientific theories should take into account of only observable indicators such as stimulus0response sequence.

According to Skinner;

The mentalist problem can be avoided by going directly to the prior physical causes while bypassing intermediate feelings or state of the mind. The quickest way to do this is to consider only those facts which can be objectively observed in the behavior of one person in relation to his/her prior environmental history [15].

This theory is very relevant to this study because nonformal art training involves the transmission of information from master to apprentice, and this is essentially the transmission of the response appropriate to a certain stimulus, thus, the point of education is to present the student/learner with the appropriate repertoire of behavioural responses to specific stimuli and to re-inforce those responses through an effective re-enforcement schedule.

It is a known fact that traditional wood carving training consists an effective re-enforcement schedule that requires constant repetition of techniques, small progressive sequences of task and continuous positive re-enforcement. Without positive re-enforcement, learned responses will quickly become extinct. This is because learners will continue to modify their behavior until they receive some positive re-enforcement.

According to Low Enfield and Brittan.

For a child art is primarily a means of expression. No two children are alike, and in fact each child differs even from his earlier self as he constantly grows, perceives understands and interprets his environment. A child is a dynamic being, art becomes for him a language of thought [16].

From these positions of most scholars on the subject of research, the affective domain (character training) occupies the most important position in both the informal and formal educational system in wood carving and indeed the whole art training.

\subsection{Empirical Studies}

This section looks at previous empirical researchers on the subject matter. These works provide a lot of insight into Nigerian educational system for example. Taiwo, took a look at Nigerian educational system from a historical perspective, from pre-colonial period to present. While trying to categorize them under; pre-colonial, colonial and post-colonial systems of education. Taiwo emphasized the importance of each system to the community when he stated that, "there are education for living in conformity with the traditions of the community; there is also education for occupation and economic self-reliance and 
education for special occupation" [17].

Taiwo's work is relevant to this study and both share the view that traditional/non-formal system of education still exist in present day society. However, his work fails to comment on the influence of non-formal/traditional education on our contemporary formal education. Emphasis on such relationship is important since learning cannot be restricted but should be all encompassing.

Nwofor (2014) in his study of the "Awka Wood Carving Industry", analyzed the economic prospects of wood carving in Awka town and outlined its relevance in alleviating the economic problems and unemployment among the youths in the society. The study also describes the decline of Awka wood carving industry and calls for collective effort toward reviving the ailing traditional industry. Nwofor's work is very relevant to his present study, however both differ in scope because his study concentrated mainly on techniques, prospects and problems of Awka carving industry [18].

Adepegba in Nigerian Art Traditions and Modem Tendencies did a survey of Nigerian art from its earliest traditions to the present time. This work shares familiar opinion with this study since both emphasize contemporary art in Nigeria including its wood carving tradition as almost a continuation of traditional art [19]. Similarly, Susan Vogel in her Africa explores, carried out a panoramic survey of contemporary African arts and crafts with emphases on non-formal trained artists. She insists that African artist trained in formal arts schools (universities and polytechnics) lack originality and their works were imitations of western art. Vogel's opinion is misleading since it is obvious that present day African wood carvers who are mainly formal trained still retain a lot of links with traditional/non formal art training and practice [20].

Amanke Okafor devoted a large space on Awka wood carving while writing the history of Awka people. He identified the period of Nigeria Biafra CivilWar (19671970) as a period of decline in the industry and mentioned efforts made to revive it through the Awka Carvers CoOperative located at Amawbia after the civil war [21].

A clear influence of non-formal art training on formal/contemporary art was documented by Opara in "Icons of Power: Continuity and Change in Carved Church Doors in Owerri Archdiocese". Here Opara opines that contemporary Owerri carved doors could be identified as a continuity of Owerri creative wood carving heritage.

Owerri, albeit, Igbo wood carving heritage were produced by traditional carvers who are products of nonformal training. From Opara's viewpoint, their works show great inventiveness and flexibility, it also influence and dominate the styles of the contemporary carved church doors in Igboland. This could be seen in the preponderance use of traditional motifs, derived mainly from Uli and Ichi repertoire. These Igbo motifs when juxtaposed with Christian motifs yield an eclectic form of sacred art [22].

Another similar work that tries to show the influence of informal/non-formal art training on formal/contemporary artists is by Okolo Bardi, who in "A Survey of Informally Trained Pioneer Artists in Edo State," classified the modern/contemporary Benin art into two groups: the formally trained pioneer artists and the informally trained ones.

Bardi traced the foundation of modern Benin art to the traditional Benin artists whose training were based on the apprenticeship system. This was followed by the new or contemporary Benin art which emerged with the arrival of the missionaries in Benin in 1473 which ushered a new trend in their arts. It is of great advantage that their style, technique and education systems sread greatly to influence an average Benin contemporary artist [23].

Bardi's work is very significant to this study because it did not only project contemporary Benin/Nigerian art as a continuation of traditional art but tried to establish that the so called originators of modern art in Nigeria were greatly influence and indeed products of informal and non-formal systems of education.

Among contemporary artists in Nigeria exist a group known as commercial artists. These groups of artists are not only products of the apprentice but could be seen as a matrix for understanding the level of influence of nonformal art training on formal art.

Manasseh Imonikebe in his "Contemporary Art in isoko land, Delta state, Nigeria: a Survey of Commercial Artists at the Close of the $20^{\text {th }}$ Century" investigated the trend and growth of these category of contemporary artists.

Imonikebe's work reveals an unparalleled role of their interface (between traditional and modern art) which serve as a quick-response to meet the daily artistic need of the people. The significance of this work to the present study lie on its effort to further emphasize the continuity in the long establish artistic tradition of informal/non-formal art education [24].

\subsection{Summary of Literature Review}

From the works reviewed, one discovers that training in wood carving in Nigerian could be acquired through formal training, non-formal and in-formal methods. Literature area available on Nigeria, Igbo and Awka wood carving from the earliest tradition to the present time, but they are not sufficient and were written mainly from an anthropological view point, not art education.

Works such as Okafor, [25]and Nwofor [26] centered on wood carving in Awka however, their works mainly emphasized the aspect of decline of the wood carving industry without attention on the obvious perceived influence of Awka traditional wood carving training, which was non-formal and present day formal training of wood carvers in Awka. A few literature such as Carrol [24] and others focused on influences and adaptation observable in the training of contemporary African carving from tradition/non-formal carving. However, these works were 
concentrated on Yoruba culture and other parts of Nigeria with little or no mention of Awka wood carving tradition.

In all its obvious from available literature and to the best of the knowledge of the researcher that this study "Perceived Influence of Non-Formal Education on Training and Practice of Contemporary Wood Carving in Awka Town", is a pioneer work and tries to fill perceived identified gaps in the area.

\section{Methodology}

\subsection{Research Design}

This chapter is presented under the following subheadings: Research design, Area of the study, population, sample and sampling technique, instrument for data collection, valuation of the instrument, reliability of the instrument, methods of data collection, method of data administration and method of study analysis.

The study employs a survey research method. The survey is a non-experimental and descriptive research method of obtaining exact facts about a current situation through sampling a population, or persons possessing at least one common characteristic. It is very valuable in obtaining data from a non-observable phenomenon Nwabueze, [28]

\subsection{Area of the Study}

This study was conducted in Awka town of Anambra state. Awka is the capital of Anambra state located at the heart (53) of the state. It is bounded in the South by Enugu state.

Awka town is an Igbo community of the present-day Anambra State. Awka is the administrative headquarters of
Awka South Local Government Area and the capital of Anambra State.

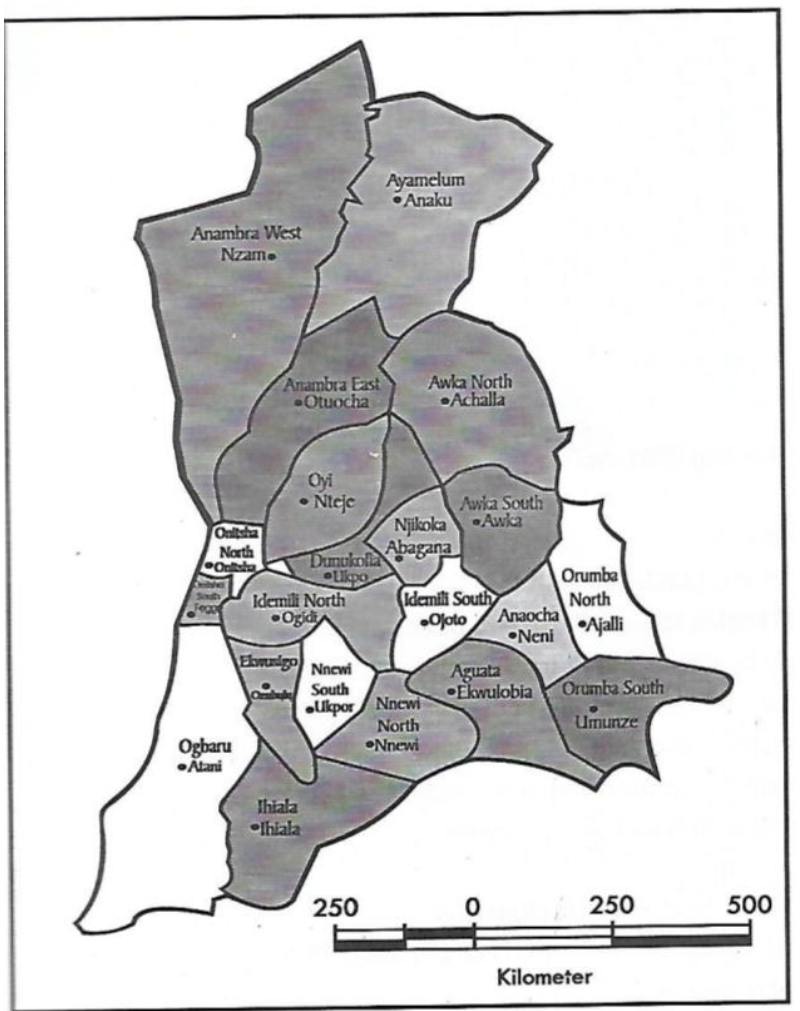

Figure 1. Map of Anambra State showing Local Government Areas

Awka south local government is made up of many towns namely: Nibo, Amawbia, Mbaukwu, Umuawulu, Awka town among others. Nibo town which is situated at the south east end is the closest town to Awka and separated by obibia stream. Okpuno and Isu-Aniocha towns in Awka south local government area are the nearest western neighbours. 


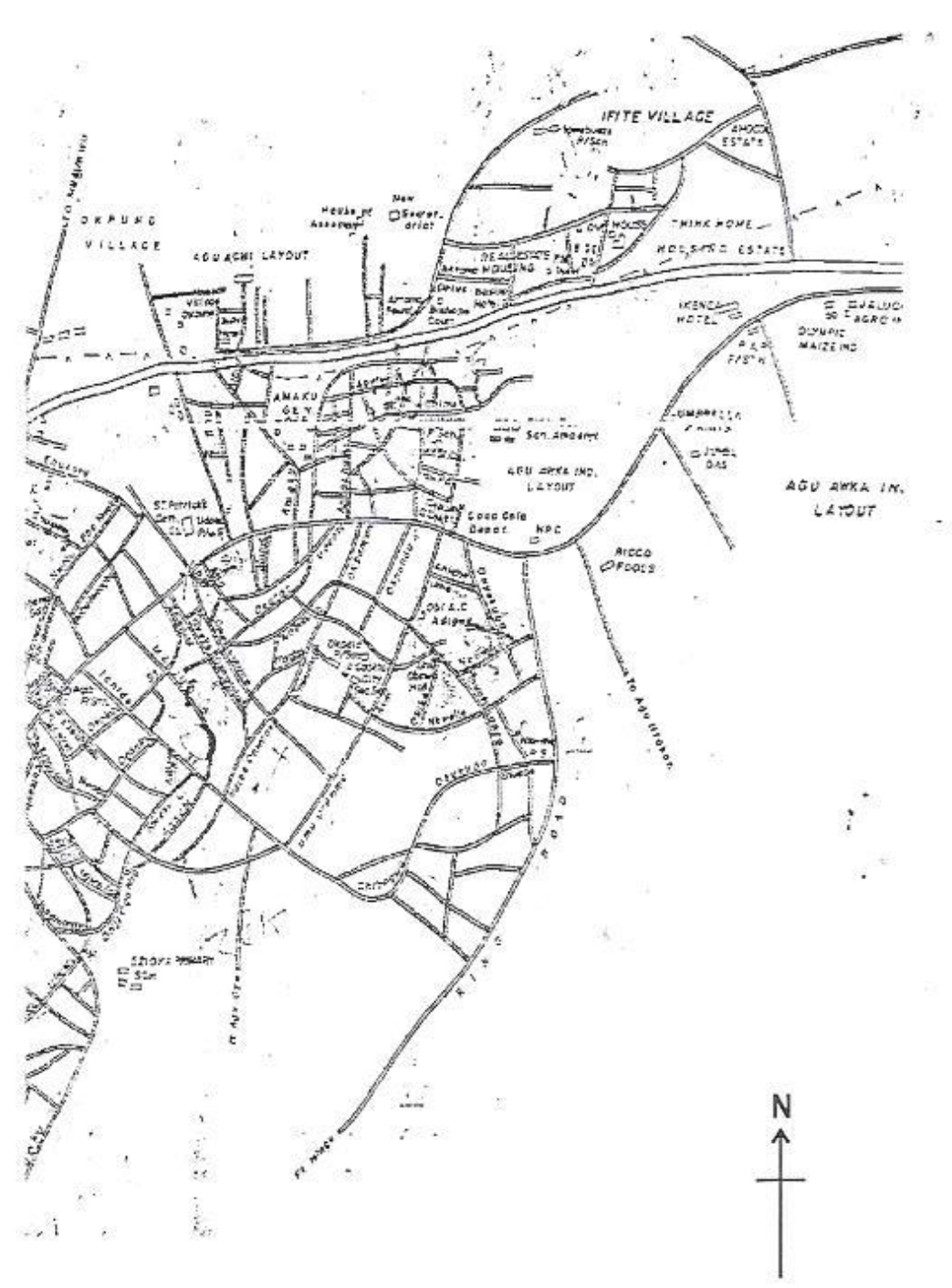

Figure 2. Showing Awka Street guide, courtesy Vineplan \& Partners

Awka town situates 22 miles from Onitsha and 45 miles to Enugu. It is the largest town between Onitsha and Enugu.

Awka is in the rain forest region, having two seasonal climatic conditions which are the rainy and dry seasons, with a short period of harmattan. The period of many trends to be the hottest during the hot climate condition and the town experiences very coolclimate between December and January, during which the atmosphere generates a scotching cold weather in the afternoon and misty weather in the early morning hours. Though Awka town has no major river, there are a number of streams and springs which supply water for household chores to the inhabitants. The pipe-borne water system that was in use since the colonial times is no longer in existence, in its place people now sink bore holes for both private and commercial purposes.

There are divergences in the composition of the soil ranging from loamy soil with immense agricultural potentialities in the north and north-east, to the sandy soil in the south and south-west, where corn, and vegetable can be cultivated. Generally, agricultural communities around
Awka and they supply the town with food all year round. The topography of the area presents a panorama of scenic beauty consisting of vast lowlands, western and northern plains and hills which traverse the other parts of the area.

\subsection{Cultural History of Awka}

Early Awka culture history is imprecise and speculative because of scarcity of written records which precedes $16^{\text {th }}$ century A. D and archeological data which could help in reconstructing the available fragments gotten mostly from oral sources. Despite these handicaps, the study relied on facts emerging from anthropological and art historical field work, studies of language, oral traditions, archaeological finds and colonial records, to work towards an Awka history and help to explain the life of the Awka-Igbo as they are known today.

The origin of Awka town takes the pattern of other Igbo communities which depend mainly on oral tradition since there are not much of archeological evidence which could be used for reconstruction of the early history of the people. 
Unlike some Hausa-fulani towns, they have no literary tradition which dates back to the sixteenth century and beyond. Despite the absence of conventional records of the early history of Awka, some theories can be identified.

The first is the theory of autochthony which is very popular among Awka people. Awka people believe that they have continuously inhabited their present location since the beginning of the world. This theory of independent generation is supported by Okafor (1992) who stated that;

Umueri, Ayom-na-Okpala and Okpo, the three Ifiteana communities also called themselves Umuoka or Oka began their entry into the remembered history in the banks of Ogwugwu stream in what is now Nkwelle village and they all lived there. Amaenyi, Amachala and Umueri who were original Awka emigrated to where they now live from Amaenyi [29].

According to oral tradition, Obe was the oldest quarter in Awka town and some other villages might have sprung from the same parent stock, while others immigrated into Awka and become absorbed into Amachalla village. Presently two major divisions exist in Awka town, "Ezi and Ifite." The two divisions consist of four clans; Agulu, Amikwo, Ezioka and Amaenyi. In all, they make up the thirty-three villages of Awka town.

The second theory of origin is based on an Awka mythology which states that centuries ago when men in this part of the world wandered from one place to another in search of suitable place to settle and toil for subsistence, a man known as Nneoshi found himself at a town called Ugwuoba. He settled there and began to raise a family. Nnoshi had two sons: Ugwuoba and Awka, it was traditional in those days for the first son of a man (diokpala) to occupy his obu (family house). His brother, Awka, then decided to establish his own obu, Hence, he moved southwards and settled at this place now called Awka. As Awka began to expand into several villages, two major assimilations occurred.

The first was that of Nnebuzu, a master smith from Agulu-Umana in what is now called Ezeagu Local Government Area of Enugu State, was said to have settled in Awka. His name Nnebuzu translates to Nebo the smith.

This tradition has it that it was Agulu that introduced blacksmithing into Awka.

Nnebuzu later took a wife from Awka and raised children but was survived by only one son called Agulu. Agulu grew up to take over his father's profession (Blacksmithing) and became affluent. He had many wives and nine children, eight males and one female. 


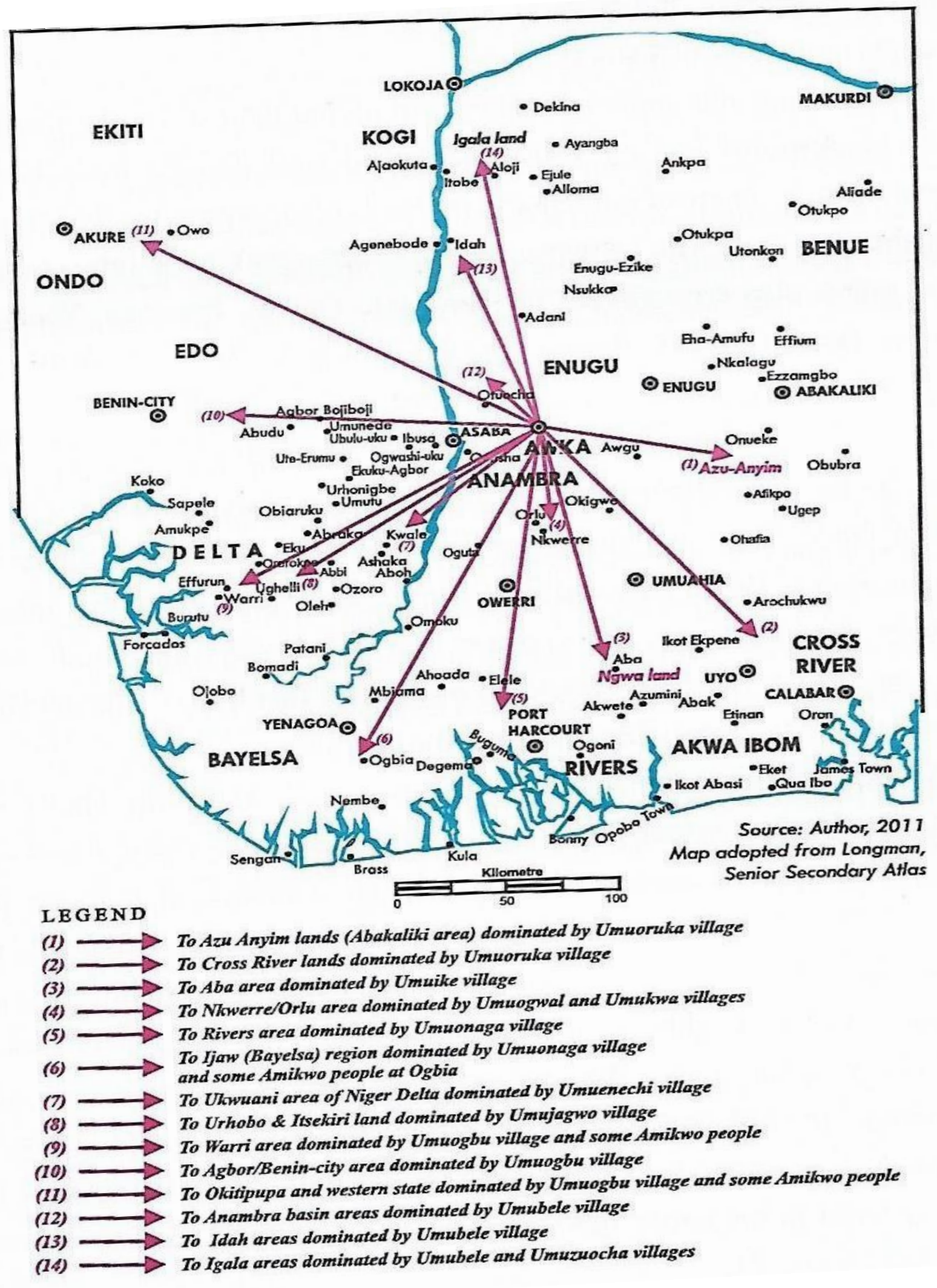

(C) Awka (1800-2000). A Survey of the History and Traditions of the Ancient city - state.

Figure 3. Section of Nigeria showing the Trade routes of internerant Awka Blacksmiths by 1900

His sons are: Umuogbu, Umubele, Agulu, Umuonaga, Umujawon, Umuenechi, Umuoruka. The eight Oro came from the same mother with Umuogbu so both lived in the same locality. These sons of Agulu are the fore bear of the Agulu group of villages. The only girl child was Omoado, whom Okpanam from Amaenyi married.

\subsection{Economic Life of Awka People}

The ingenuity, creative skill and expressive style of the
Awka wood carver is exhibited by the design and texture given the wood in the final finishing process.

\subsection{Population of the Study}

The study covered the seven traditionalquarters/sections of Awka town namely; Ayomna Okpala, Nkwelle, Amachalla, Ifite, Amikwo, Ezi-oka and Agulu. In all, the population of people interviewed for the study is limited to fifty people; educated, uneducated, elderly persons and 
wood carvers: the sample study was also extended to cuturalists who value art and its aesthetic relevance.

\subsection{Sampling and Sampling Technique}

In this research, Random Sampling Technique was employed. A sample population was drawn from the seven traditional quarters/sections of Awka town namely; Ayomna-Okpala, Nkwelle, Amachalla, Ifite, Amikwo, Ezi-oka and Agulu. The sample size for the study is limited to fifty (50) respondents. Fifty questionnaires were distributed with equal representation to elicit their opinions on the present state of wood carving in Awka and the perceived influences in informal training on the present formal practice. Systematic random sampling was employed in selecting respondents for the survey.

\subsection{Method of Data Collection}

The researcher employed mainly the method of oral interview and questionnaire for data collection; the procedure involved personal interviews with some of Awka traditional historians and wood carvers and some contemporary carvers whose studies/workshops were personally visited by the researcher in order to observe their production techniques. Photographs of sample of their works were also taken. The questions were simple, direct and unambiguous to elicit appropriate response and relevant information. Twenty questions in all which were close ended, where the respondents are required to select answers from these provided in the questionnaire. The questionnaires were administered personally by the researcher to the respondents for clear the concept and to facilitate adequate information from the respondents. The questionnaires were validated by Dr. Ivan Okonkwo, a Lecturer in Art Education at Nnamdi Azikiwe University, Awka.

\subsection{Method of Data Analysis}

As an empirical study efforts were made to employ appropriate statistical methods of presentation and statistical methods of presentation and analysis. Frequency tables and simple percentages were utilized in presenting the data. The Hypothesis were statically tested using t-test, of the difference between two means, and Pearson product moment correlation Co-efficient. For the $\mathrm{t}-$ test, the two means comprise evidence from Non-formal art and formal trained arts practice. The mean values of the appropriate indicators were calculated and compared. The significance of the difference was tested using the $\mathrm{t}$ - Test.

\subsection{Method of Data Administration}

Here the researcher administered questionnaires and conducted interviews in order to understand the nature and working techniques of Awka carvers photographs of works they produced were also taken and analyzed.

\subsection{Method of Data Adminis tration}

The $t$ - test is inferential statistics used to determine whether there is a significant difference between the means of two groups. It is appropriate in this study since the difference between the mean of the set standard and that of the data collected were tested and the sample size is small. The person moment correlation co-efficient was utilized because it enabled the researcher to measure the strength between variables and relationships and to determine the strength of the relationship between two variables.

\section{Presentation of Data Analyses}

A total of fifty questionnaire copies were distributed to fifty people within the area of the study and all were completed and returned. The analysis of the data obtained from fifty (50) respondents revealed that the importance and relevance of informal education on contemporary wood carving training and practice in Awka.

\subsection{Demography Presentation of Data}

Table 1. Age distribution of Respondents

\begin{tabular}{ccc}
\hline Age range & Number of respondents & Percentage (\%) \\
\hline $20-40$ & 11 & 22.0 \\
$41-60$ & 15 & 30.0 \\
60 and above & 24 & 40.0 \\
\hline Total & 50 & $100 \mathrm{~s}$ \\
\hline
\end{tabular}

From the distribution table, age range 20-4- years has 11 respondents constituting $22 \%$ while age range 41-6- years has 15 respondents constituting $30 \%$ and 60 years and above has 24 respondents constituting $40 \%$.

Table 2. Occupational Distribution of Respondents

\begin{tabular}{ccc}
\hline Occupation & $\begin{array}{c}\text { Number of } \\
\text { respondents }\end{array}$ & $\begin{array}{c}\text { Percentage } \\
(\mathbf{\%})\end{array}$ \\
\hline Art students & 17 & 34 \\
\hline Non-artists & 21 & 42 \\
\hline $\begin{array}{c}\text { Professional wood } \\
\text { carvers }\end{array}$ & 12 & 24 \\
\hline Total & $\mathbf{5 0}$ & $\mathbf{1 0 0}$ \\
\hline
\end{tabular}

From the occupational distribution table above, 17 respondents who were art students constitute $34 \%$ while 21 respondents constituting $42 \%$ were non artists and 12 respondents constituting 24 percent were professional carvers. 
Table 3. Response on the State of Woodcarving craft in Awka

\begin{tabular}{ccccc}
\hline Question 1 & $\begin{array}{c}\text { Strongly } \\
\text { agree }\end{array}$ & Agree & $\begin{array}{c}\text { Not } \\
\text { agree }\end{array}$ & Total \\
\hline $\begin{array}{c}\text { Awka town is } \\
\text { renowned for wood } \\
\text { carving craft }\end{array}$ & 47 & 0 & 3 & 50 \\
\hline Percentage (\%) & 94 & 0 & 6 & $100 \%$ \\
\hline
\end{tabular}

Table 4. Determining the popularity of Woodcarving in Awka Today

\begin{tabular}{ccccc}
\hline Question 2 & Good & Neglected & Poor & Total \\
\hline $\begin{array}{c}\text { What is the present status } \\
\text { of wood carving in Awka } \\
\text { today? }\end{array}$ & 26 & 20 & 4 & 5 \\
\hline Percentage $(\%)$ & 52 & 40 & 8 & $100 \%$ \\
\hline
\end{tabular}

From the table we could see from the response that wood carving craft in Awka is still thriving.

Table 5. Assessment of the Influence of the informal training on contemporary Woodcarving

\begin{tabular}{ccccc}
\hline Question 3 & $\begin{array}{c}\text { Great } \\
\text { extent }\end{array}$ & $\begin{array}{c}\text { Considerably } \\
\text { extent }\end{array}$ & $\begin{array}{c}\text { Little } \\
\text { extent }\end{array}$ & Total \\
\hline $\begin{array}{c}\text { What is your } \\
\text { assessment of the } \\
\text { influence of the } \\
\text { informal training } \\
\text { on contemporary } \\
\text { wood carving }\end{array}$ & 26 & 20 & 4 & 50 \\
\begin{tabular}{c} 
Percentage $(\%)$ \\
\hline
\end{tabular} & 94 & 0 & 6 & $100 \%$ \\
\hline
\end{tabular}

From the table, we see that the responses that support the idea that informal education has a lot of influence on contemporary wood carving in Awka.
Table 6. Determining the extent of influence informal carving training on the products and services of contemporary woodcarving

\begin{tabular}{ccccc}
\hline Question 4 & $\begin{array}{c}\text { Great } \\
\text { extent }\end{array}$ & $\begin{array}{c}\text { Considerable } \\
\text { extent }\end{array}$ & $\begin{array}{c}\text { Little } \\
\text { extent }\end{array}$ & Total \\
\hline $\begin{array}{c}\text { To what extent has } \\
\text { the informal carving } \\
\text { training influences } \\
\text { the product and } \\
\text { services of }\end{array}$ & 30 & 14 & 6 & 50 \\
$\begin{array}{c}\text { contemporary wood } \\
\text { carving in Awka? }\end{array}$ & & & & \\
\hline Percentage $(\%)$ & 60 & 28 & 12 & $100 \%$ \\
\hline
\end{tabular}

In the table 6 , respondents constituting $60 \%$ agreed that carving craft bears a lot of influence on the products and services of contemporary Awka wood carvers.

Table 7. Economic prospects of Wood carving in Awka

\begin{tabular}{ccccc}
\hline Question & Flourishing & Dying & Dead & Total \\
\hline $\begin{array}{c}\text { Rate the economic } \\
\text { prospects of wood } \\
\text { carving in Awka in } \\
\text { relation to the socio- } \\
\text { economic life of the } \\
\text { peoples }\end{array}$ & 45 & 4 & 1 & 50 \\
\hline Percentage (\%) & 90 & 8 & 2 & $100 \%$ \\
\hline
\end{tabular}

From table 7 wood carving craft is still thriving in Awka today.

Experience has shown that among the various models of training available to Youths art training which belongs to the apprentice training experience stands out among the rest as could be seen from the table.

Table 8. Showing Educational Training Experiences in Nigeria 1980-2000 C F. Onwusoba (2015) [30]

\begin{tabular}{|c|c|c|c|}
\hline & Apprenticeship Training Expe rience & $\begin{array}{c}\text { Functional/Technological Training } \\
\text { Experience }\end{array}$ & $\begin{array}{c}\text { Grammar School Training } \\
\text { Experience }\end{array}$ \\
\hline 1. & $\begin{array}{c}\text { Training skill through the eagle eye of a } \\
\text { master }\end{array}$ & $\begin{array}{l}\text { Training both right and left brain for } \\
\text { technological skill acquisition }\end{array}$ & $\begin{array}{l}\text { Training the brain for3R's; } \\
\text { arithmetic, reading and writing }\end{array}$ \\
\hline 2. & $\begin{array}{c}\text { Training for a specific role in productive } \\
\text { industry }\end{array}$ & Training to actualize self reliance & Training for a white job collar job \\
\hline 3. & Training to master for a number of years & $\begin{array}{c}\text { Training to retain others for number of } \\
\text { years }\end{array}$ & $\begin{array}{c}\text { Training for self and a number of } \\
\text { years }\end{array}$ \\
\hline 4. & Training for increased productivity & $\begin{array}{l}\text { Training for job creation and employment } \\
\text { for self and others }\end{array}$ & $\begin{array}{l}\text { Training for certificate for } \\
\text { government already made job }\end{array}$ \\
\hline 5 . & $\begin{array}{l}\text { Training for products that increase will } \\
\text { attract demand and supply }\end{array}$ & Training for all the increased productivity & $\begin{array}{c}\text { Training for earning income, from } \\
\text { government }\end{array}$ \\
\hline 6. & $\begin{array}{l}\text { Training on the job for skills needed for a } \\
\text { better tomorrow }\end{array}$ & $\begin{array}{c}\text { Training for a better and improved nation } \\
\text { building }\end{array}$ & $\begin{array}{l}\text { Training cannot erase redundancy and } \\
\text { unemployment in the society. }\end{array}$ \\
\hline
\end{tabular}




\subsection{Interpretation of Data Analysis}

From the research carried out, it revealed that Awka towns was renowned in wood carving craft. From table 4, it is observed that most of the respondents observed that wood carving is a thriving business today in Awka town. Table 5 revealed that the perceived influence of informal training on contemporary wood carving in Awka is high.

From table 6, it is evident that majority of the respondents agreed that there is a perceived influence of informal education on the products and services of contemporary Awka wood carvers.

From table 7 it was observed that the wood carving craft is still thriving in Awka today.

The data collected from the tables show that although Awka wood carving industry has undergone various stages of metamorphosis, there is a perceived influence of informal education in the practice today. Such informal education system has its roots in the pre-colonial Africa. Pictures below show the similarities between the work of a formal trained wood carver and a non-formal/traditional wood carver.

The influence of informal education that has been carried from generation to generation has bequeathed Awka carving craft with its own unique and distinctive styles and the standardized the quality of its products. It was also protected by traditional Awka wood carvers Guild. Even though wood carving craft is still booming in Awka town, a lot could still be done to improve on its present state, so that it will help to check youth employment, poverty alleviation and manpower development.

\section{Conclusions, Summary and Recommendations}

\subsection{Conclusions}

The research work looked into wood carving in Awka from the pre-colonial period to the present. It established among other things that wood carving profession is an ancient craft that is as old as Awka civilization. The researcher examined the techniques, problems and prospects of wood carving craft in Awka and found out that there is a resilience of informal education pattern in the profession, which could still be seen in its present-day practice.

The study also observed that there was a gradual decline in Awka wood carving industry, from the advent of Christianity to the post-colonialera. Even with such decline Awka woods carving still stands out among other wood carving centres, mostly because of its unique style of straight and sharp linear pattern. One can say that there is a continuity in the profession although the present generation of wood carvers also engage in other aspects of sculpture.

In all wood carving industry in Awka holds a lot of promise if the informal education system integrated with the formal wood carving training which are taught in the various art centres, all over Nigeria. The major limitation of this study is the lack of literature on Awka contemporary wood carving.

\subsection{Recommendations}

This study recommends that Nigerian government should change from their leisser-fair attitude towards Awka wood carving. There should be a concerted effort from the government towards encouraging Awka wood carving industry.

Again, there is need for the carvers to come together to form guild/corporative, where they can pull their resources together for their collective and common good, such guild system exists among Edo wood carvers in Benin where they are known as the Igbesenwa Guild of Carvers.

The curriculum for teaching academic wood carvers should be designed after the informal educational patter, which existed in the African traditional setting.

There is also need for carving to be introduced in the primary schools to acquaint the children with the artistic skill of wood carving. Carvers could organize sensitization programmes, such as seminar, art exhibitions and workshops for upcoming carvers. All these will go a long way towards sustaining the Awka wood carving industry.

\section{Appendix}

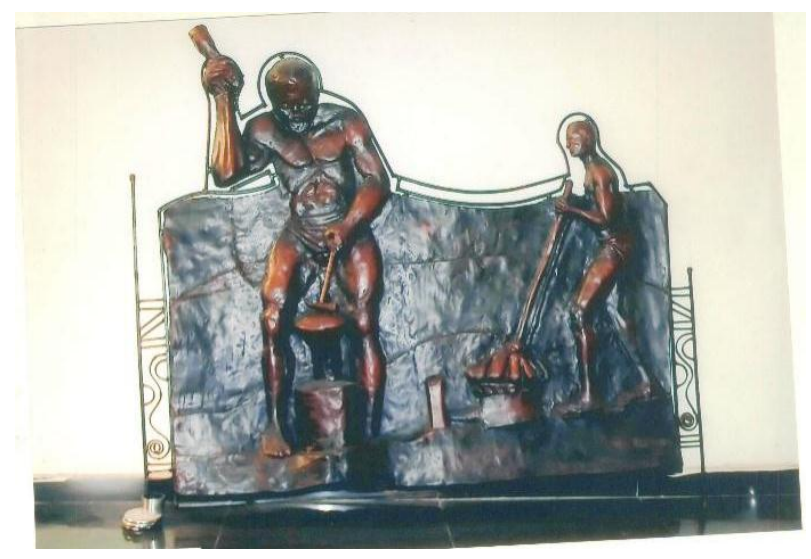

Plate 1. Work of a contemporary/formal artist from Awka: Cliff Nwanna, showing an Awka Blacksmith and his apprentice at work.

\section{REFERENCES}

[1] Amaele, S. A Study Guide on History and Policy of Education in Nigeria, Ilorin: NDEM AC Nig pub. Ltd, 2003

[2] Odiboh, F Abayomi Barber: The Politics of African Art, Benin: Digit All Books 2018. 
[3] Amaele, S. A Study Guide on History and Policy of Education in Nigeria, Ilorin: NDEM AC Nig pub. Ltd, 2003

[4] Kasfir, S. Contemporary African Art, London: Thames and Hudson Ltd, 1999

[5] Awogbade, M. O "Out of-school Education in the visual Arts, An Anthology of Modern Nigerian Arts and Related Issues Zaria: Department of Fine Arts, Ahmadu Bello University, 2010.

[6] Salpyman B. Skill Acquisition through the Apprenticeship System: A useful (or valuable) practice in Arts and Craft, Journal of Business Education, Melete: Kwara State University.

[7] Bardi, 'A'. A Survey of the Informally Trained Pioneer Artists in Edo State, AJOFAA, Awka Journal of Fine and Applied Arts, Awka: Department of Fine and Applied Arts, UNIZIK 2014

[8] Basden, G. T. Niger Ibos, London: Frank Cass 1964

[9] Ogugua Ikechukwu, Philosophy and metal working, AJOFAA, Awka Journal of Fine and Applied Arts, Awka: UNIZIK, 2014.

[10] Grombrich, H. Art and Illussion, London: Phaidon Press 1960

[11] Grombrich, H. Art and Illusion, London: Phaidon Press 1960

[12] Veron, Eugene, Aesthetic Theory of what is Art, Journal of Aesthetics and Art Criticism, New York: Wiley - Blackwell 1983.

[13] Leo Tolstoy, What is Art: An Introduction to Philosophy, New York: words worth and Thompson 2004

[14] Anyaeji, I, Beyond ExpirationDate: Exploring up cycling, AJOFAA, Awka Journal of Fine and Applied Arts, Awka: Department of Fine and Applied Arts, Nnamdi Azikiwe University, 2014.

[15] Skinner, B.F About Behaviorism, New York: Vintage Books, 1976

[16] Lowenfield and Brittan (1975) Creative and Material Growth New York: Macmillan Publishing.

[17] Taiwo, Co. The Nigerian Educational System, Past Present and Future, Lagos: Thomas Welson Nig Ltd 1980, Nwabueze (2013). Research Methods, An Integrated Approach ( $2^{\text {nd }}$ Edition) Enugu: ABIC Books \&Equipt. Ltd. P. 62.

[18] Nwofor, O. (2008). Wood Carving in Awka: problems and prospects, An unpublished project submitted to the Department of Fine and Applied Arts 2018, NnamdiAzikiwe University, Awka.

[19] Adepegba Cornelius, Nigerian Art and its Modem Tendencies Ibadan; Jodad press, 1995 Basden G.T. (1966) Niger Ibos London: Frank Cass.

[20] Susan Vogel, African Art Explores: $20^{\text {th }}$ Centry African Art, Newy ork: African Art Centre 1991

[21] Amanke Okafor, Awka People, Onitsha: Manila Press, 1991.

[22] Opara, J. k. "Icons of Power: Continuity and Change in Carved Church Doors in Owerri Archdiocese, Owerri:
Okpulo Journal of Arts and Cultural Heritage, National Commission for Museum and Monuments 2014.

[23] Bardi, Augustine "The Role of Centers: A Look at Patrick Igbobedhere Agose's works and Influence in Universal Studios of Art, Lagos Nigeria". Maidugari Journal of Arts and Design (MAIDJAD). Maidugari: Department of Visual and performing Arts, Faculty of Arts University of Maidugari, Vol III, 2017

[24] Imonikebe, M. Contemporary Art in Isokoland, Delta State, Nigeria: A Survey of Commercial Artists at the close of the $20^{\text {th }}$ Century, 2014.

[25] Amanke Okafor, Awka People, Onitsha: Manila Press, 1991

[26] Nwofor, O. (2008). Wood Carving in Awka: problems and prospects, An unpublished project submitted to the Department of Fine and Applied Arts 2018, NnamdiAzikiwe University, Awka

[27] Carrol Kevin, Yoruba Craft Work at Oye Ekiti, Ondo Province, Nigeria Magazine, Federal Ministry of Information, 1958

[28] Nwabueze, Emeka, Research Methods, An Integrated Approach ( $2^{\text {nd }}$ Edition $)$ Enugu: ABIC Books \& Equipt Ltd, 2013

[29] ]Amanke Okafor, Awka People, Onitsha: Manila Press, 1991

[30] Onwusoba, F. Art, Security and Nation Building, JOSONAA,Journal of the society of Nigerian Artists, Anambra Chapter vol.2 Awka: SNA, Anambra, 2015.

[31] Ogugua, I. Philosophy and Metal woking, AJOFAA Awka Journal of Fine and Applied Arts, Awka: Nnamdi Azikiwe University, 2014. Okafor, A. Awka People Onitsha: Manila Press, 1991

[32] Sulyman, B. A. (2007). "Skill Acquisition through the Apprenticeship system: A useful (or valuable) Practice in Arts and Crafts,"

[33] Tolstoy, L. (2004) What is Art: An Introduction to Philosophy, New York: Words Worth and Thomson P. 675. 